\title{
Saving Energy Using Local Available Insulation Materials in Erbil
}

\author{
Ali Mahmood Ibrahim¹, Ramzi R. Ibraheem², Rizgar Bakr Weli ${ }^{3}$ \\ ${ }^{1}$ Mechanical Engineer, Ministry of Electricity-KRG \\ ${ }^{2}$ College of Engineering, Salahaddin University, Erbil, Kurdistan Region - Iraq \\ ${ }^{3}$ College of Engineering, Salahaddin University, Erbil, Kurdistan Region - Iraq
}

\begin{abstract}
An experimental study has been carried out to investigate how much energy may be saved through the use of thermal insulation in the walls and roofs of buildings, experimental tests were done to show percentage of saving energy in walls and roofs. The experimental result shows that the maximum energy saving for the walls when using Rockwool as insulation is75.1\% but when using of extruding polystyrene (XPS), it is $73.9 \%$. Similarly, for the roof the results are $66.6 \%$ and $61.1 \%$ respectively. A theoretical method based on annual energy saving using Degree-Day Method, has been employed for Erbil city. The percentage of energy saving using Rockwool, in case of walls is $77.9 \%$ for heating, and it is $78 \%$ for cooling. In the similar manner the percentage of energy saving for Erbil city is $77.3 \%$ for heating, and cooling when using xps, in case of walls but for the roofs the percentage of energy saving is $80.5 \%$ for heating and cooling when using rock wool and $80.1 \%$ when using XPS.
\end{abstract}

KEYWORDS : Insulation, Thermal Conductivity, Green Building, Heat Transfer, Energy Saving, Construction Materials, Smart Building.

\section{INTRODUCTION}

Energy demand is increasing day by day due to urbanization, industrial growth and population growth. The growth of population will lead to high energy consumption in fields of heating and cooling for airconditioning purposes. Adding of insulation to the walls and roofs will cause the reduction in reducing cooling and heating loads in the buildings and industrial establishments. in this paper the insulation materials of extruding polystyrene (XPS) and rock wool are used as insulation materials as they are available in local market in Erbil in suitable price. G.C. Bakos [1] used the different type of insulation materials to investigate the energy saving in the city Kavala in the Nothern part of Greece and evaluated the energy consumption before and after enveloping the building by suitable thermal insulation. Mohammad and Khawaja [2] used the different insulation materials to determine the optimum thickness of insulation to reduce the rate of heat flow to the buildings in hot countries and minimize the bill of electricity for the building lifetime.O.A. Dombayci [3] used expanded polystyrene as insulation material in the external wall of buildings. He concluded that energy consumption reduced by $40.6 \%$. Ali Bolatturk [4] used thermal

Academic Journal of Nawroz University

(AJNU) Volume 7, No 4 (2018).

Regular research paper : Published 21 December 2018

Corresponding author's e-mail :

ali.mahmood8599@yahoo.com

Copyright @2017 Ali Mahmood Ibrahim, Ramzi R.

Ibraheem², Rizgar Bakr Weli ${ }^{3}$

This is an open access article distributed under the Creative

Commons Attribution License. insulation in external walls. The results show that optimum insulation thickness ranges from 2-17 cm; payback duration is $1.3-4.5$ years and savings of energy are $22-79 \%$. He concluded that the optimum insulation varies between 3.2 to $3.8 \mathrm{~cm}$ based on cooling degreehours. Subhash Mishra et al. [5] used different types of building walls; brick, concrete and stone. Extruded polystyrene in (XPS) and expanded polystyrene are used as insulation material. The optimum thickness of insulation is in the range of 5.2 and $7.4 \mathrm{~cm}$. in the present work the extruded polystyrene XPS and rock wool are used as insulation materials with $5 \mathrm{~cm}$ thickness which is near the optimum as deduced in the preceding papers and they are available in the local market with reasonable prices.

\section{Theory}

The energy saving estimation is done using basic heat transfer equations and specified in equations bellow and also using the degree day method.

\subsection{Heat Transfer from Walls and Roofs}

In buildings, the heat transfer through walls and roofs is dominated by conduction and convection. Typically, one-dimensional heat conduction is considered to be adequate for above-grade building components unless significant thermal bridges exist such as at the wall corners or at the slab edges. Specifically, the heat transfer from a homogeneous wall or roof layer illustrated in Figure 3.1 can be calculated as follows using the Fourier law:

$\mathrm{q}=\mathrm{KA} / \mathrm{x} *(\mathrm{Ti}-\mathrm{To}) \ldots \ldots \ldots \ldots . . .2 .1$

Where

$\mathrm{R}=\frac{\mathrm{x}}{\mathrm{k}}=\frac{1}{\mathrm{U}} \ldots \ldots \ldots \ldots \ldots \ldots .2 .2$

where

$h$ the convective heat transfer coefficient of the surface. 
The concept of thermal resistance can be extended to convection heat transfer that occurs at the outer or inner surfaces of the building envelope [Z. Otkay].

$\mathrm{R}_{\mathrm{i}, \mathrm{o}}=\frac{1}{\mathrm{~h}} \ldots$ .2 .3

In buildings, a wall or a roof consists of several layers of homogeneous materials as illustrated in Figure 3.2.The heat transfer from a multi-layered wall or roof can be found by determining first its overall $R$-value.

$$
\begin{aligned}
& \mathrm{R} \mathrm{t}(\mathrm{w})=\mathrm{Ri}+\frac{\mathrm{x}}{\mathrm{k} \text { gypsum }}+\frac{\mathrm{x} \text { block }}{\mathrm{k} \text { block }}+\frac{\mathrm{x}}{\mathrm{k} \text { cement }}+\mathrm{Ro} \\
& \text {..2.4 } \\
& \mathrm{Rt}(\mathrm{w}+\mathrm{ins})=\mathrm{Ri}+\frac{\mathrm{x}}{\mathrm{k} \text { gypsum }}+\frac{\mathrm{x} \text { ins }}{\mathrm{k} \text { isu }}+\frac{\mathrm{x} \text { block }}{\mathrm{k} \text { block }}+\frac{\mathrm{x}}{\mathrm{k} \text { cement }}+ \\
& \text { Ro ................2.5 } \\
& \mathrm{R}(\mathrm{r})=\mathrm{Ri}+\frac{\mathrm{x} \mathrm{slab}}{\mathrm{kslab}}+\mathrm{Ro} \ldots . .2 .6 \\
& \mathrm{R}(\mathrm{r}+\mathrm{ins})=\mathrm{Ri}+\frac{\mathrm{x} \mathrm{slab}}{\mathrm{kslab}}+\frac{\mathrm{x} \text { ins }}{\mathrm{k} \text { isu }}+\mathrm{Ro} \ldots \ldots \ldots .2 .7
\end{aligned}
$$

\subsection{Degree day method}

The degree-days method provides an estimation of the heating and cooling loads of a building due to transmission losses through the envelope and any solar and internal heat gains. The degree-days method is based on steady-state analysis of the heat balance across the boundaries of the building based on indoor temperature of $18{ }^{\circ} \mathrm{C}(65 \mathrm{~F})$ [7]

D. $\mathrm{D}=$ no. of day in month $*(\mathrm{~Tb}-\mathrm{To}) \ldots \ldots . .2 .8$

$\operatorname{HDD}(\mathrm{Tb})=\sum_{\mathrm{i}=1}^{\mathrm{NH}}(\mathrm{Tb}-\mathrm{Toi}) \ldots \ldots \ldots \ldots \ldots \ldots . .2 .9$

$\mathrm{CDD}(\mathrm{Tb})=\sum_{\mathrm{i}=1}^{\mathrm{NH}}(\mathrm{Toi}-\mathrm{Tb}) \ldots \ldots \ldots \ldots \ldots \ldots . . .10$

(Moncef Krarti, second edition. 147)

Amount of heat passing through the wall and roof by conduction in one direction flow

$\mathrm{q}=-\mathrm{kAdT} / \mathrm{dx}=\mathrm{A}$ * $\left(\mathrm{T}_{2}-\mathrm{T}_{1}\right) / \mathrm{R}_{\text {total }}=\left(\mathrm{T}_{2}-\mathrm{T}_{1}\right)$ * $\mathrm{A}^{*} \mathrm{U}$ total........................... 2.11

Energy through the wall and roof

$\mathrm{E}=\mathrm{q}^{*}$ time................................... 2.12

Heat loss per unit area of external wall

$\mathrm{q}=\mathrm{U} *(\mathrm{~T}$ in $-\mathrm{T}$ out $)$

................................................2.13

Heat gain of external wall

$\mathrm{q}=\mathrm{U} *(\mathrm{~T}$ out $-\mathrm{T}$ room $) \ldots \ldots \ldots \ldots \ldots \ldots \ldots \ldots . . .2 .14$

The annual heat per unit area, qann can be determined using the degree day method.

$\mathrm{E}_{\mathrm{ann}}=(86400 * \mathrm{U} * \mathrm{D} . \mathrm{D})$

3. Experimental rig setup

The local building wall model in Erbil in almost cases are consisting of $2 \mathrm{~cm}$ gypsum plastered in inner side, 20 $\mathrm{cm}$ hollow concrete block of main wall and $2 \mathrm{~cm}$ concrete plastered on the outer surface, and the roof is of $20 \mathrm{~cm}$ reinforced concrete with $2 \mathrm{~cm}$ gypsum plastered at inside. This type of buildings is very cold in winter and very hot in summer. in this paper the insulation is applied to the walls and the roof, two type of insulation are used the first is extrude polystyrene and the second is rock wool both of $5 \mathrm{~cm}$ in thickness.

\subsection{The test rig preparation}

The experiments were done on a set of two identical housing model units. One was insulated with extrude polystyrene and Rockwool insulation and the other identical unit was un-insulated model for walls and roofs. The walls of buildings in Kurdistan are done usually using hollow cement block with dimensions of $(40 * 20 * 20 \mathrm{~cm})$ and these walls are plastered by $2 \mathrm{~cm}$ of cement plastered from outside and $2 \mathrm{~cm}$ gypsum plastered from inside. The wall with insulation the model is provided by $5 \mathrm{~cm}$ insulation material of rock wool or xps polystyrene. The roof model is prepared according to the standards civil engineering codes with dimensions $(40 * 20 * 20 \mathrm{~cm})$, iron steel bars of $12 \mathrm{~mm}$ diameter are used the space between the steel bars is 14 $\mathrm{cm}$. There are two layers with $15 \mathrm{~cm}$ spacing between the two layers of steel bars. The steel bars will be in the middle and $2.5 \mathrm{~cm}$ cover of concrete above and down of the steel mesh. The roof concrete construction is a mixture of cements, sand and gravel with ratio of 1:2:4 by weight respectively. Water is added to the mixture and after mixing the mixture well, the mixture is poured in to the mould and it left to dry. The roof is spread by water from time to time to get the strong roof. A circular hole is done to model in the outer and inner surface for inserting thermocouple wires for temperature measurement. each model is placed on flat plate heater for heating the models and checking the difference in the temperature difference between inside and outside for different type of models to determine the effect of thermal insulation on energy saving.

\subsection{Experimental procedure}

The steps carried out during the test can be out lined below

1.the bottom side is subjected to direct heating by the electric heater..

2.The top side is left free for atmosphere.

3 . The other four sides are completely insulated by $5 \mathrm{~cm}$ of fibreglass and are surrounded by wood mould to hold and support the fibreglass insulation tightly.

The main devices used in the experimental work are as follows:

1. Thermocouples of K- type.

2. Digital multi meter to record the temperature.

3.Stop watch.

4. Watt meter for measuring voltage, current and power consumption.

5. An electric heater as a source of heat of dimensions $\left(45^{*} 24 * 3 \mathrm{~cm}\right)$ model, as shown in figure (3.1).

After putting the wall or roof model on the heater the heater, is switched on, and the temperatures of the upper and lower sides are recorded every 15 minutes. The same procedure is repeated for all prepared wall and roof models with and without insulation. The experimental results revealed the effect of insulation on heat transfer through the models. the construction of the wall without insulation is shown in figure (3-2) 
The construction of the wall after applying insulation is shown in figure (3-3). The thermal resistance of the walls with and without the thermal insulation are shown in tables (3.1), (3.2), and (3.3)

\section{RESULTS AND DISCUSSION}

Figures (4.1) shows the change of inside wall gypsum plastered surface temperature and outside wall cement plastered surface temperature with time for four hours (240 minutes). Measurements were taken at every 15 minutes. Outside surface temperature increases with time from $\left(22^{\circ} \mathrm{C}\right.$ to $\left.65^{\circ} \mathrm{C}\right)$ and inside surface temperature increases from $\left(22{ }^{\circ} \mathrm{C}\right.$ to $\left.30^{\circ} \mathrm{C}\right)$, it means that inside gypsum plastered surface temperature $\left(\mathrm{T}_{2}\right)$ increases only $\left(8^{\circ} \mathrm{C}\right)$ during four hours by heating the wall. Figure (4.1) shows the change of temperature with time for the wall with extruded polystyrene (XPS) as insulation, for four hours but in this figure when outside temperature increases with time from $\left(19^{\circ} \mathrm{C}\right.$ to $\left.68^{\circ} \mathrm{C}\right)$, inside surface temperature increases from ( $19{ }^{\circ} \mathrm{C}$ to $21^{\circ} \mathrm{C}$ ). Inside gypsum plastered surface temperature $\left(\mathrm{T}_{2}\right)$ increases only $\left(2^{\circ} \mathrm{C}\right)$ during four hours $(240$ minutes) of heating. The results of this test indicate that when extruded polystyrene is used as insulation for the external wall, the change of inside gypsum plastered surface temperature, is less than the change of inside gypsum plastered surface temperature, of the wall without insulation. Figure (4.1) shows the change of temperature with time for the wall with Rockwool as insulation, for a period of four hours. The outside surface temperature increases with time from $\left(17^{\circ} \mathrm{C}\right.$ to $68^{\circ} \mathrm{C}$ ) and the inside surface temperature increases from $\left(17{ }^{\circ} \mathrm{C}\right.$ to $\left.18{ }^{\circ} \mathrm{C}\right)$. It means that the inside surface temperature, gypsum plastered $\left(\mathrm{T}_{2}\right)$ increases only $\left(1^{\circ} \mathrm{C}\right)$ during four hours the sample was heated. The results of this test indicate that when Rockwool is used as insulation for external wall inside gypsum plastered surface temperature is less than change of inside gypsum plastered surface temperature wall without insulation. The results of three tests insure that when extruded polystyrene and Rockwool were used for insulating external wall, the Rockwool is better than extrude polystyrene due to the above obtained results. The cost for each $\left(1 \mathrm{~m}^{2}\right)$ Rockwool is $6.59 \$$, while for extrude polystyrene it is $5 \$ / \mathrm{m}^{2}$ and extrude polystyrene is easy to install. Figure (4.2) represents the results for the discussion of the figure (4.1), but the presentation is done in columns. Figure (4.3) shows heat flow through the wall by conduction with (extrudes polystyrene and Rockwool) and without insulation. During four hours (240 minutes) the wall sample was heated, each data recorded at every 15 minutes; the results show that amount of heat transmission through the wall without insulation is more than the amount of heat transmission through the wall with the addition of two types of insulation. (Extruded polystyrene and Rockwool). The amount of heat passing through the wall when Rockwool was used as insulation is less than the amount of heat passing through the wall when extruding polystyrene was used. It means that the Rockwool is better than the extruded polystyrene for energy saving. Percentage of energy saving by extruded polystyrene it is $73.9 \%$, but for Rockwool, $75.1 \%$ and the reason is that, the overall heat transfer coefficient of the Rockwool is less than that of extruded polystyrene. Figure (4.4) shows the temperature change of the roof at inside and outside of the roof with insulation and without insulation and it is clear that the inside roof temperature is increased $31^{\circ} \mathrm{C}$ in four hours of heating the outer surface and getting the steady state of the outer surface at $68^{\circ} \mathrm{C}$ and inner surface at temperature at $41{ }^{\circ} \mathrm{C}$. The situation changes as the insulation added to the upper side of the roof, and in case of XPS the inside temperature rise is $5^{\circ} \mathrm{C}$ while in the case of Rockwool the increase of temperature is only one degree and this better than that of the previous case. Figure (4.5) shows the heat flow through the roof by conduction with and without insulation, using (extruded polystyrene and Rockwool). Four hours of heating, the data's were recorded every 15 minutes. The results show that the amount of heat flow through the roof without insulation is more than the amount of heat flow through the roof with insulation (extrude polystyrene and Rockwool). The amount of heat loss through the roof when Rockwool is used as the insulation is less than that when extrude polystyrene is used as insulation. using of degree day method the total heating degree day is $938.4{ }^{\circ} \mathrm{C}$ while the cooling degree day is $2116{ }^{\circ} \mathrm{C}$, in Erbil city, so that the energy saving using insulation are as follow :

using XPS :

Heating energy saving $=150.3 \mathrm{MJ} / \mathrm{m}^{2}$ and cooling energy saving $=338.51 \mathrm{MJ} / \mathrm{m}^{2}$.

using Rockwool:

Heating energy saving $=151.5 \mathrm{MJ} / \mathrm{m}^{2}$ and cooling energy saving $=341.31 \mathrm{MJ} / \mathrm{m}^{2}$.

Total energy saving during one year $=341.3+151.51=$ $492.81 \mathrm{MJ} / \mathrm{m}^{2}$

the energy saving in case of money saving in 10 years will be about $26.853 \$ / \mathrm{m}^{2}$, and this result is in good near to the results obtained by [9].

\section{CONCLUSIONS}

In this study, the experimental and theoretical concept of energy saving of buildings have been investigated by using thermal insulation; extrude polystyrene and rock wool for wall and roof. The following points are concluded from the study:

1. Rock wool is a suitable thermal insulation for walls and roofs to save energy, and the maximum percentage of energy saving for external walls is $75.1 \%$, during four hours in experimental study. The percentage of energy 
saved to roof $66.6 \%$ during four hours of the experimental study.

2.Maximum percentage of energy saving by using extrudes polystyrene for insulation external wall and roof, are follows

A. It is $73.9 \%$ for the external wall during four hours of experimental study.

B. It is $61.1 \%$ for roof during four hours of the experimental study.

3. Due to the flexibility of Rockwool, so that Extrude polystyrene (XPS) is better to be used for the roof.

4. Extruded polystyrene (XPS) is easier in installation than the Rock wool.

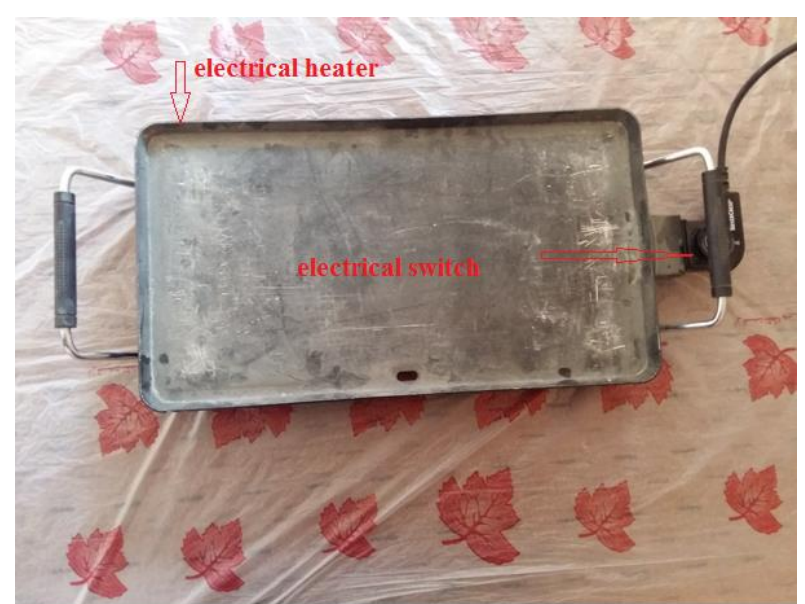

Fig (1) : The main electrical heater used in experimental work

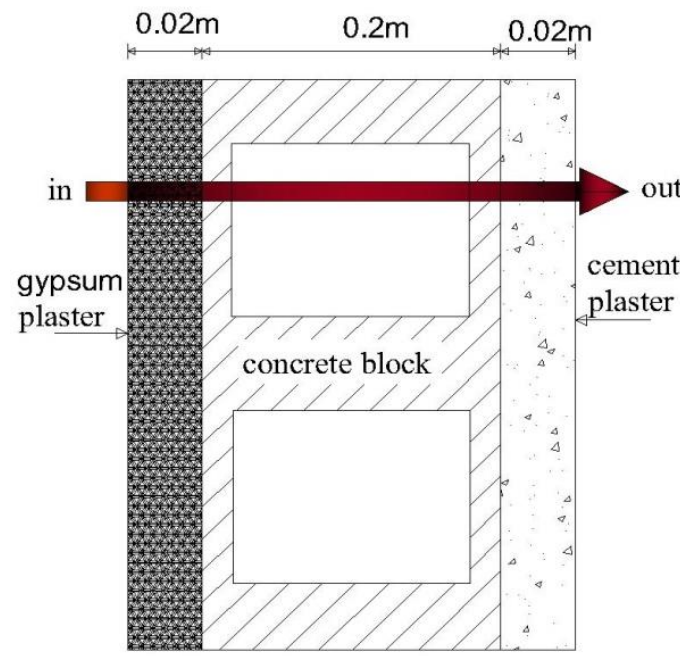

heat flow direction in winter

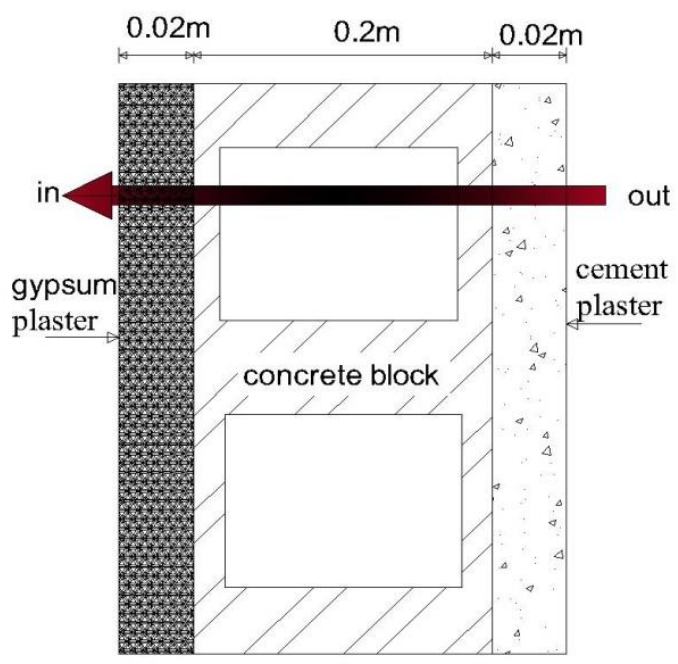

heat flow direction in summer

Fig (2) : Construction of wall without insulation

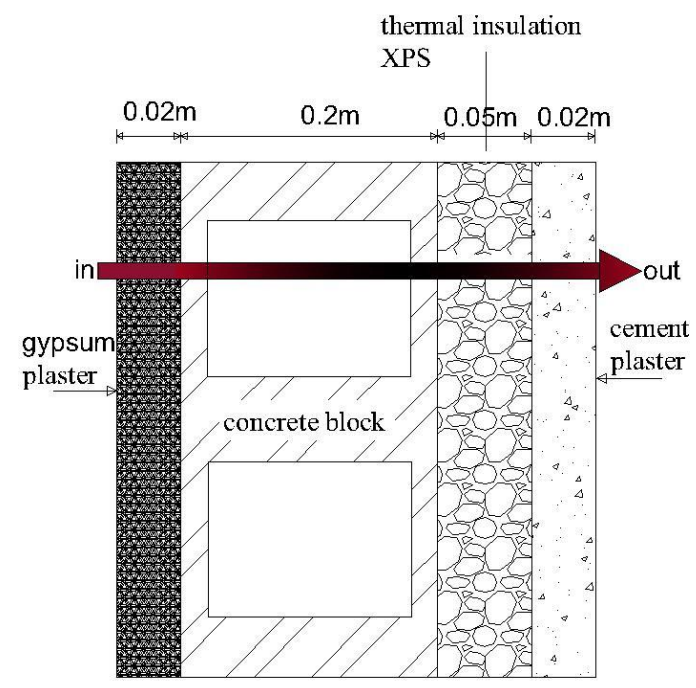

heat flow direction in winter

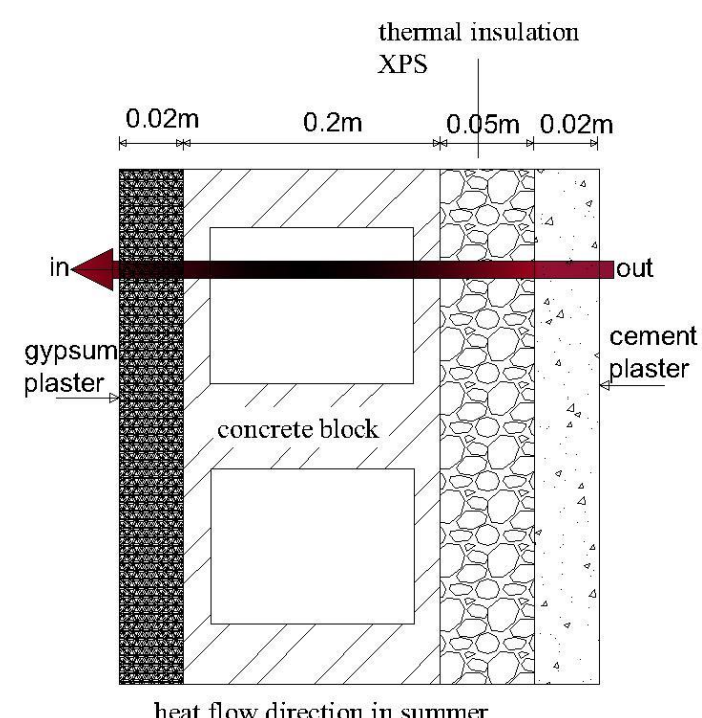

heat flow direction in summer

Fig (3) : Construction of wall without insulation 
Table (1) : physical properties of the materials of external wall without insulation

\begin{tabular}{|c|c|c|c|}
\hline Constituent & Thickness $\mathbf{m}$ & $\begin{array}{c}\text { Thermal conductivity } \\
\mathbf{W} / \mathbf{m} . \mathbf{K}\end{array}$ & $\begin{array}{c}\text { Resistance } \\
\mathbf{m}^{2} \mathbf{. K} / \mathbf{W}\end{array}$ \\
\hline $\begin{array}{c}\text { Internal plaster - } \\
\text { gypsum }\end{array}$ & 0.02 & 0.57 & 0.035 \\
\hline $\begin{array}{c}\text { Concrete block } \\
\text { hollow }\end{array}$ & 0.2 & 1.1 & 0.1818 \\
\hline $\begin{array}{c}\text { External plaster - } \\
\text { cement }\end{array}$ & 0.02 & 0.99 & 0.0202 \\
\hline $\begin{array}{c}\mathbf{R}_{\mathbf{i}} \text { (inside air } \\
\text { resistance) }\end{array}$ & & & 0.14 \\
\hline $\begin{array}{c}\mathbf{R}_{\mathbf{o}} \text { (outside air } \\
\text { resistance) }\end{array}$ & & & 0.04 \\
\hline $\mathbf{R}_{\text {total }}$ & & & 0.417 \\
\hline
\end{tabular}

Table (2) : physical properties of the materials of external wall with insulation XPS

\begin{tabular}{|c|c|c|c|}
\hline Constituent & Thickness (m) & $\begin{array}{c}\text { Thermal conductivity } \\
\mathbf{W} / \mathbf{m} . \mathbf{K}\end{array}$ & $\begin{array}{c}\text { Resistance } \\
\mathbf{m}^{2} \mathbf{K} / \mathbf{W}\end{array}$ \\
\hline $\begin{array}{c}\text { Internal plaster - } \\
\text { gypsum }\end{array}$ & 0.02 & 0.57 & 0.035 \\
\hline $\begin{array}{c}\text { Concrete block } \\
\text { hollow }\end{array}$ & 0.2 & 1.1 & 0.1818 \\
\hline $\begin{array}{c}\text { Insulation XPS } \\
\text { External plaster - } \\
\text { cement }\end{array}$ & 0.05 & .035 & 1.42 \\
\hline $\begin{array}{c}\mathbf{R}_{\mathbf{i}} \text { (inside air } \\
\text { resistance) }\end{array}$ & 0.02 & 0.99 & 0.0202 \\
\hline $\begin{array}{c}\mathbf{R}_{\mathbf{o}} \text { (outside air } \\
\text { resistance) }\end{array}$ & & & 0.04 \\
\hline $\mathbf{R}_{\text {total }}$ & & & 1.837 \\
\hline
\end{tabular}

Table (3) : physical properties of the materials of the external wall with Rockwool

\begin{tabular}{|c|c|c|c|}
\hline Constituent & Thickness $\mathrm{m}$ & $\begin{array}{c}\text { Thermal conductivity } \\
\mathrm{W} / \mathrm{m} . \mathrm{K}\end{array}$ & $\begin{array}{c}\text { Resistance } \\
\mathrm{m}^{2} . \mathrm{K} / \mathrm{W}\end{array}$ \\
\hline $\begin{array}{c}\text { Internal plaster } \\
\text { gypsum }\end{array}$ & 0.02 & 0.57 & 0.035 \\
\hline $\begin{array}{c}\text { Concrete block } \\
\text { hollow }\end{array}$ & 0.2 & 1.1 & 0.1818 \\
\hline Rock wall & 0.05 & .034 & 1.47 \\
\hline $\begin{array}{c}\text { External plaster - } \\
\text { cement }\end{array}$ & 0.02 & 0.99 & 0.0202 \\
\hline $\begin{array}{c}\mathrm{R}_{\mathrm{i}} \text { (inside air } \\
\text { resistance) }\end{array}$ & & & 0.14 \\
\hline
\end{tabular}




\begin{tabular}{|c|c|c|c|}
\hline $\begin{array}{c}\mathrm{R}_{\mathrm{o}} \text { (outside air } \\
\text { resistance) }\end{array}$ & & & 0.04 \\
\hline $\mathrm{R}_{\text {total }}$ & & & 1.887 \\
\hline
\end{tabular}

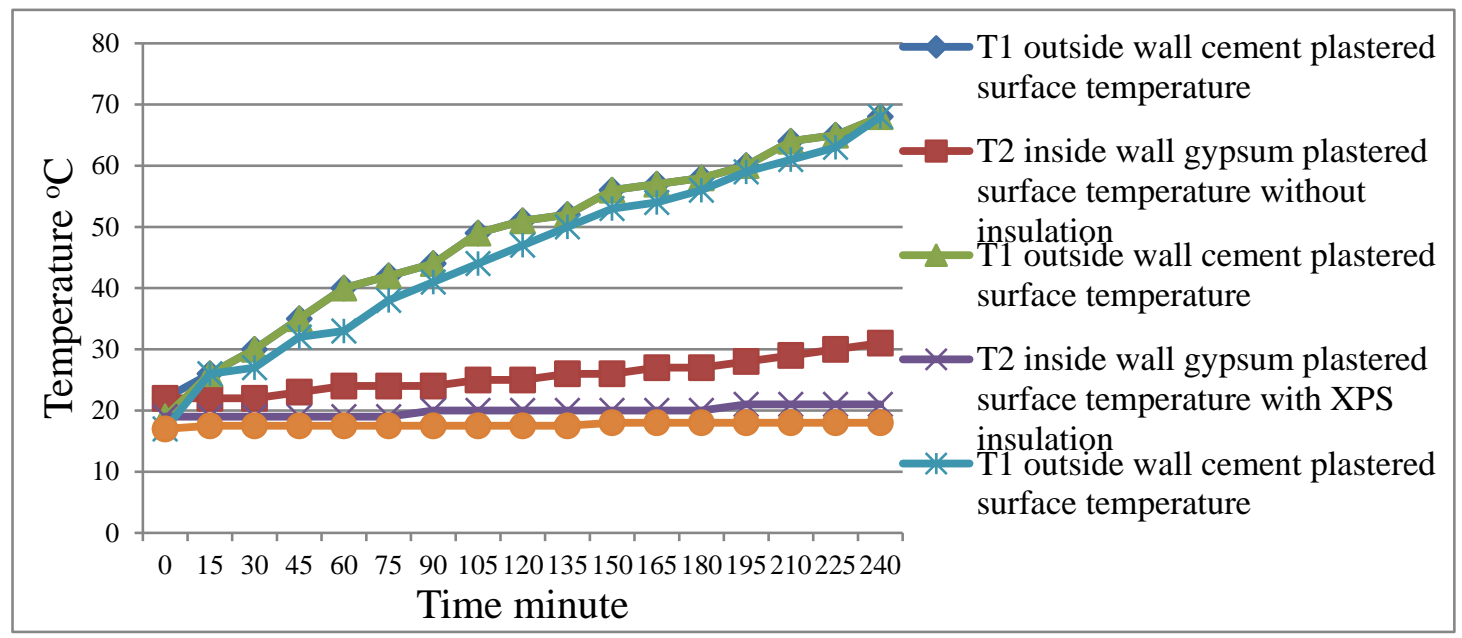

Fig (4) : Temperature change with time for the wall with and without insulation

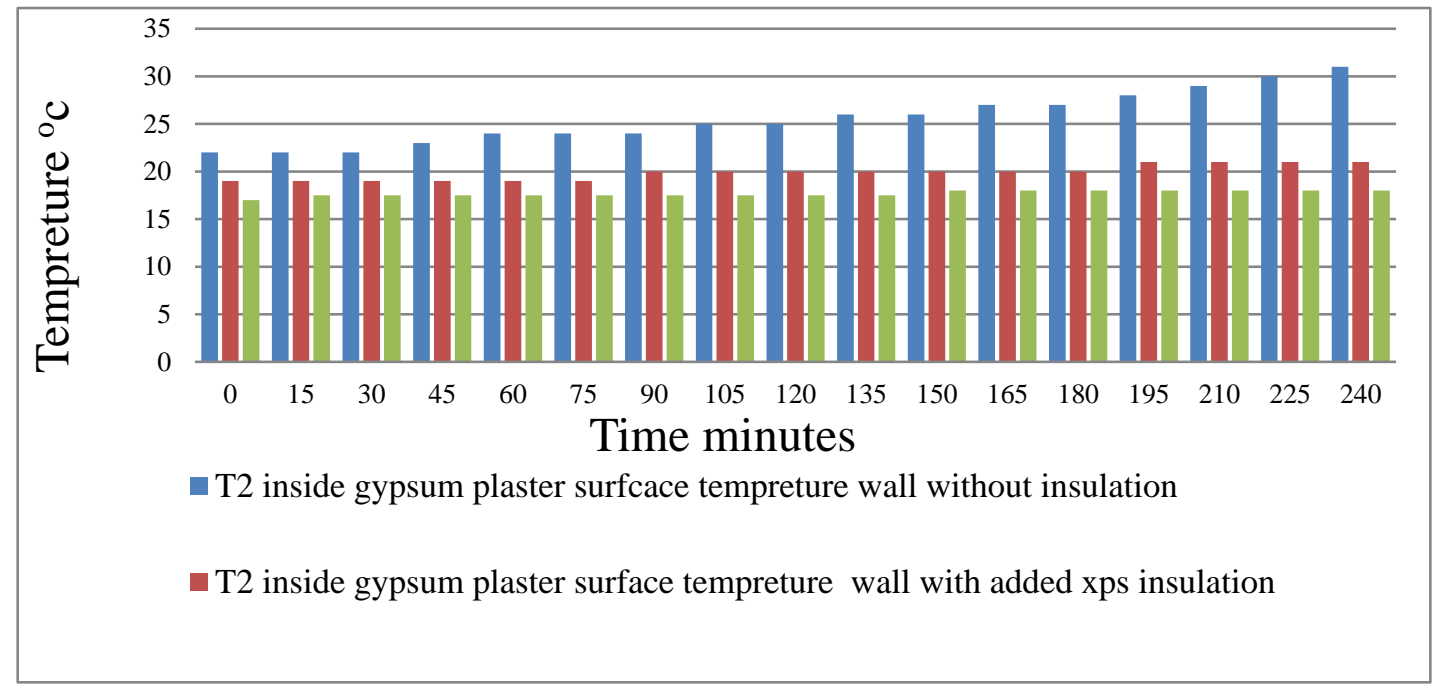

Fig (5) : Change of inside surface temperature for the wall with XPS and Rockwool insulation 


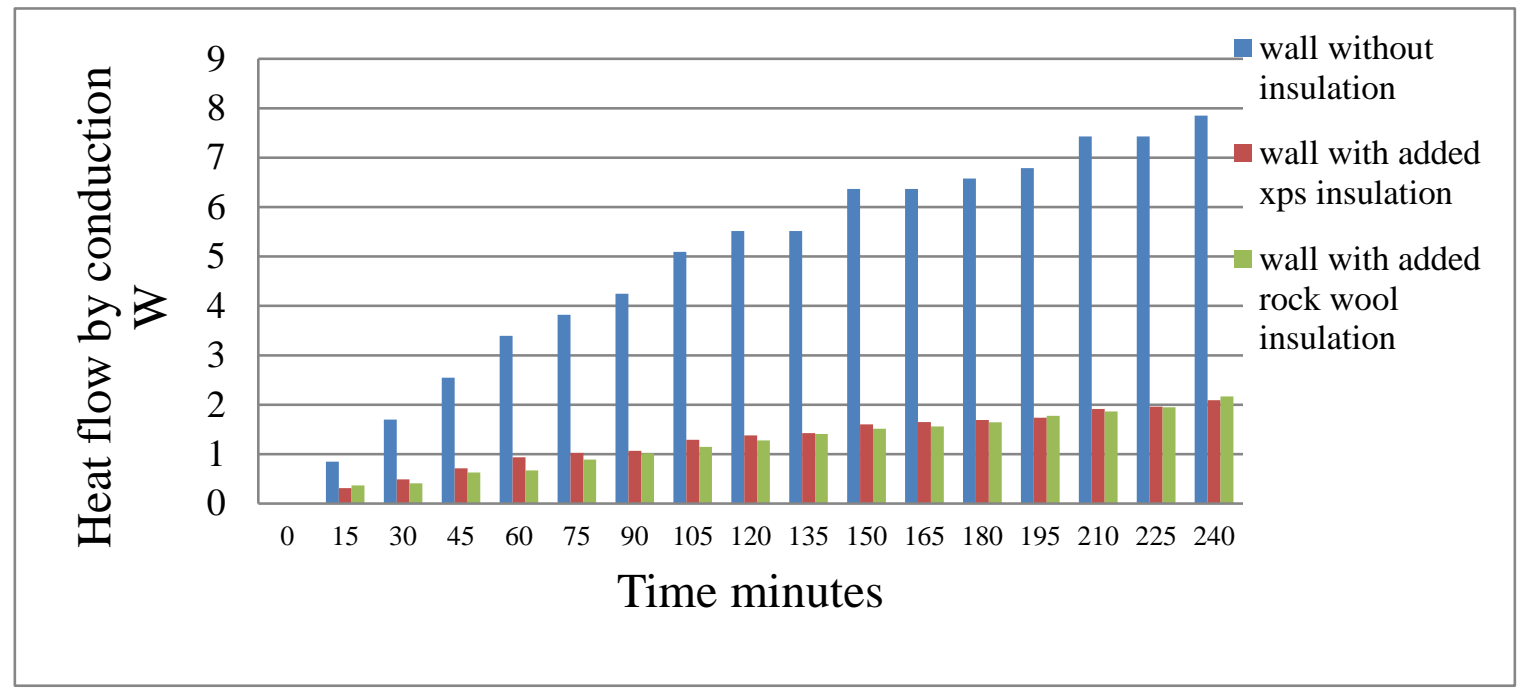

Fig (6) : Heat flow through the wall with and without insulation.

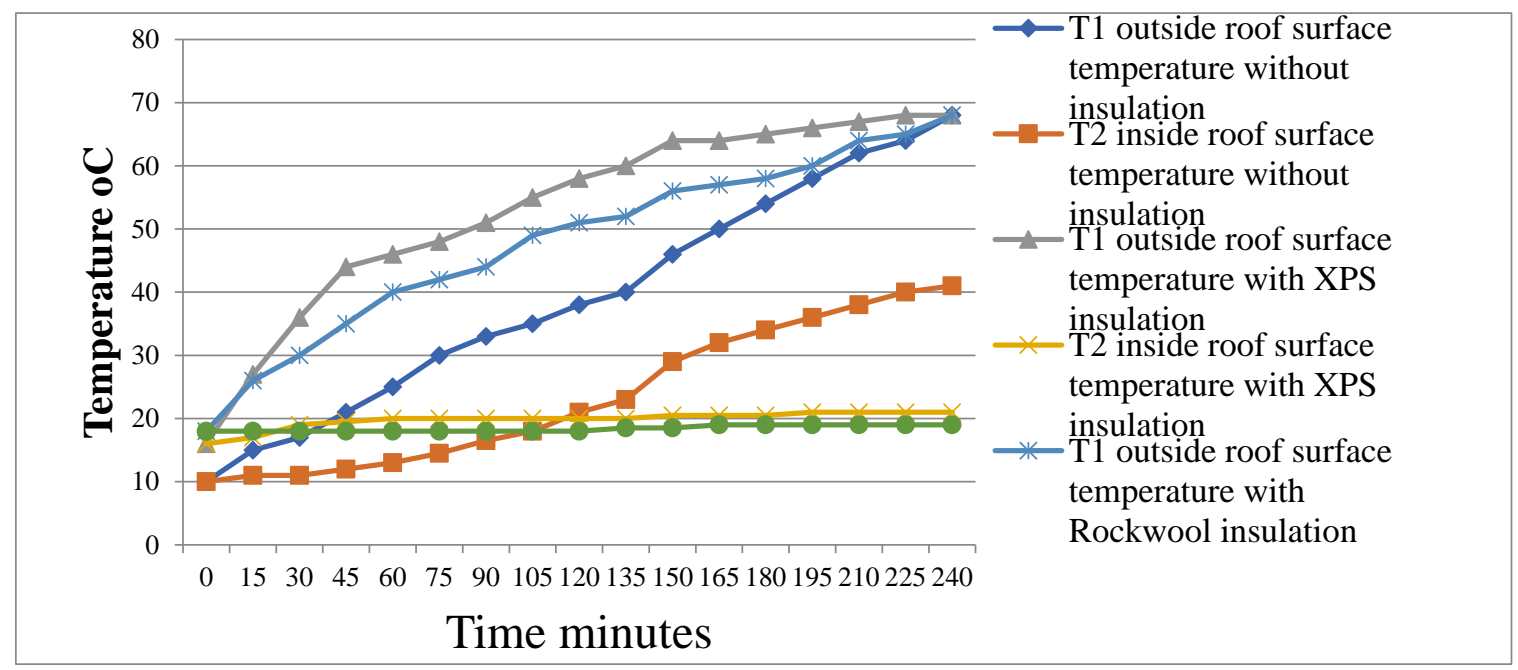

Fig (7) : Temperature change with time for roof with and without insulation.

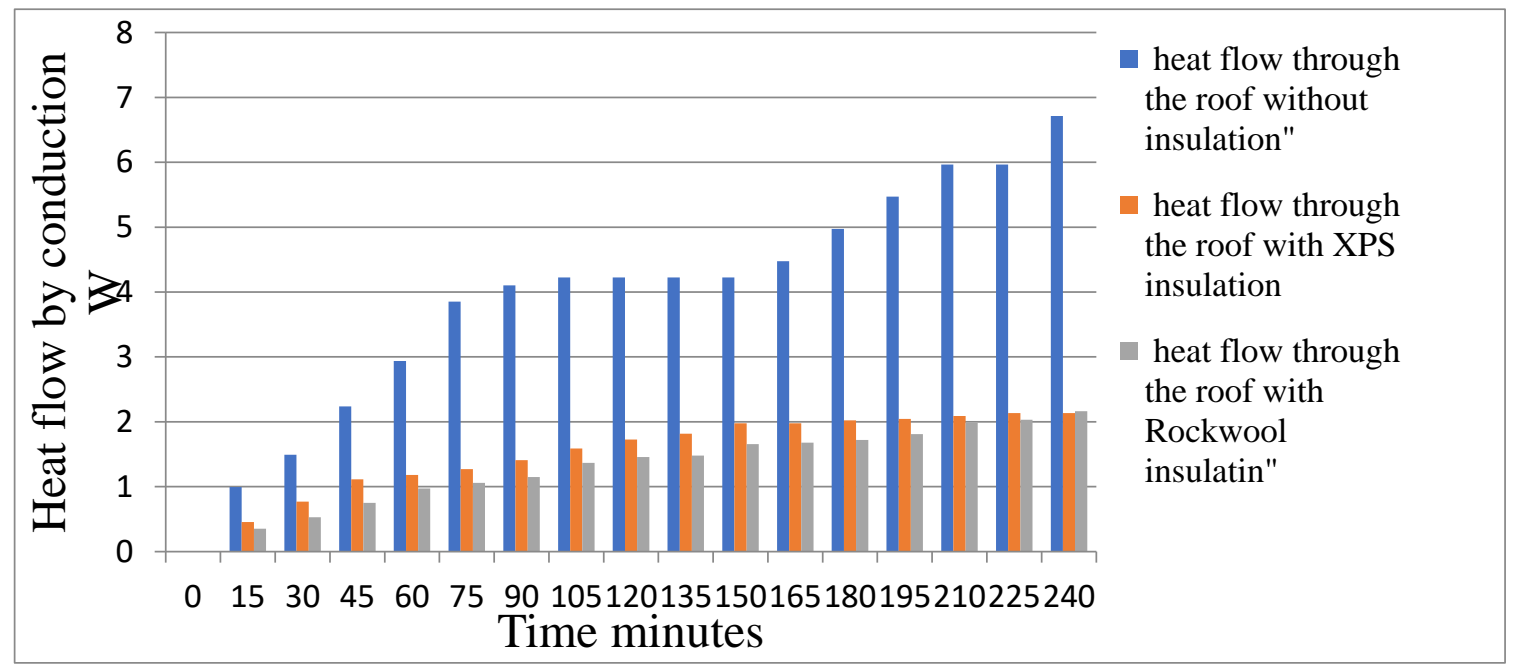

Fig (8) : Heat flow through the roof with and without insulation. 


\section{REFERENCES}

1.BAKOS G.C. (2000) Insulation protection studies for energy saving in the residential and tertiary sector, Journal of Energy and Buildings, Vol. 31.P. 251-259.

2.MOHAMMED J. AND KHAWAJA A.L. (2004) Determination and selecting the optimum thickness of insulation for buildings in hot countries by accounting for solar radiation, Journal of Applied Thermal Engineering, 24(17).p.2601-2610.

3.DOMBAYCI O.A. (2007)The environmental impact of optimum insulation thickness for external walls of buildings" Building and Environment, Vol.(42) P.P. 3855-3859.

4.BOLATTURK ALI (2008) Optimum insulation thickness for building walls with respect to cooling and heating degree-hours in the warmest zone of Turkey. Building and Environment.43(6).P.1055-1064.

5.SUBHASH MISHRA, DR. J A USMANI, SANJEEV
VARSHNEY. (2012) Energy Saving Analysis In Building Walls Through Thermal Insulation System. International Journal of engineering research and application. 2(5).September-October. P. 128-135.

6. OKTAY Z., COSKUN C. and ERTÜRK M. (2014) A New Point of View for Insulation Calculations. International Journal of Energy Engineering (IJEE). 4 (3).P.111-117.

7. ASHRAE handbook 2013.

8. KRARTI MONCEF (Second edition) energy audit of building systems an engineering approach.2011 by Taylor and Francis Group, LLC.

9.ÖZDEN AĞRA, Ş.ÖZGÜR ATAYILMAZ, HAKAN DEMIR AND İSMAIL TEKE.(2011) Environmental impact of optimum insulation thickness in buildings world. Renewable energy congress 2011-Sweden 8-13 may, Linkoping, Sweden p.p.1813-1820. 